Bangladesh J. Plant Taxon. 28(2): 395-403, 2021 (December)

(C) 2021 Bangladesh Association of Plant Taxonomists

DOI: https://doi.org/10.3329/bjpt.v28i2.57135

\title{
POLLEN MORPHOLOGICAL INVESTIGATIONS OF SALVIA L. IN SOUTHEASTERN OF TURKEY AND ITS TAXONOMIC IMPLICATION
}

\author{
Fatma Mungan KiLIÇ* \\ Department of Crops and Animal Production, Mardin Artuklu University, \\ 47200 Mardin, Artuklu, Turkey
}

Keywords: Salvia; Pollen; Light microscopy; Scanning electron microscopy; Turkey.

\begin{abstract}
In this study, the pollen morphology and exine structure of nine species of the genus Salvia L. (Lamiaceae) were investigated using light microscopy and scanning electron microscopy (SEM). Six micromorphological characters (pollen shape, polar length, equatorial width, exine and intine thickness, colpus length and colpus width) of pollen grains of Salvia have been identified. The palynological observations revealed that pollen grains of most studied taxa of Salvia were suboblate shape and possess hekzacolpate aperture. Tectal surface sculpture was a good criterion to identify particular taxa from Salvia. The pollen of which is characterized by reticulate, the pollen ornamentation was similar in all studied taxa.
\end{abstract}

\section{Introduction}

The genus Salvia L., the largest genus in the family Lamiaceae, contains about 1000 species worldwide. The genus is distributed principally in three regions, ranging from Central and South America to western Asia, and also into eastern Asia (Walker and Sytsma, 2007). The first revision of Salvia in Turkey was made by Hedge (1982), who recognized 86 species, 1 hybrid and 1 doubtful species. Since 2005, as part of a revisional study of Salvia in Turkey, the authors have carried out extensive field studies and collected a large number of specimens. Population sizes and phenological and ecological properties were also observed in the field. The studies have revealed 2 new species (İlçim et al., 2009; Celep and Doğan, 2010), 2 new varieties (Celep et al., 2009; Celep et al., 2010) and 2 new records (Celep et al., 2009; Kahraman et al., 2009). Pollen morphological characters have long been used to solve taxonomic problems in a number of plant families (Castro et al., 2009). Additionally, the authors have examined morphology, anatomy, trichome, nutlet, and pollen micromorphology of some Turkish Salvia species (Kahraman et al., 2009; Kahraman et al. 2010). Pollen morphological properties are used for identification to place a species in the correct taxonomic rank by the taxonomist (Ahmad et al., 2018). Scanning electron microscopy (SEM) has been used for the dissimilarity of species on the basis of exine ornamentation (Guimaraes et al., 2018). Aktaş et al., 2020 investigated some Turkish Salvia and they reported that palynological characters are important for differences among studied taxa.

Salvia is spreading in the province of Mardin is one of the important genera represented by four sections and nine species. The aim of this study to investigate quantitative and qualitative morphological characters of pollen of genus Salvia in Mardin, which is important for taxonomic identification.

\section{Materials and Methods}

Plant specimens were collected (Salvia bracteata Banks \& Sol., Salvia macrochlamys Boiss. \& Kotschy, Salvia suffruticosa Montbret \& Aucher ex Benth., Salvia trichoclada Benth. (sect.

*Corresponding author, E-mail: fatmamungankilic@artuklu.edu.tr 
Salvia); Salvia multicaulis Vahl (sect. Hymenosphace); Salvia montbretii Benth., Salvia palaestina Benth., Salvia syriaca L. (sect. Aethiopis) and Salvia russellii Benth. (sect. Hemisphace)) from different localities in Mardin (Table 1). Voucher samples were deposited at the Mardin Artuklu University herbarium, Turkey. All the pollen grains for light (LM) and (SEM) by the standard methods described by Erdtman (1945). Pollen grains for LM examination were prepared following the standard procedure of Wodehouse (1935). They were observed in glycerin-water using a standard Isolab microscope with D plan 1.00-1.25 160/0.17 oil immersion objective and NFKx3.3 LD 125 lens. Thirty pollen grains per specimen were regarded as sufficient for the palynological analysis. For SEM, pollen were removed by distilled water treatment, the air-dried, pollens were directly mounted on stubs using double-sided adhesive tape and uncoated. The photomicrographs were taken with a FEI Quanta Feg 250 scanning electron microscope.

Pollen shape, size, ornamentation, polar length, equatorial width, exine and intine thickness, colpus length and colpus width for 30 pollen grains were measured under binocular light microscope and Polar/Equatorial ratios were calculated. The terminology of the pollen follows that of Punt et al. (2007). For average, five readings were taken and statistically analyzed by using (IBM SPSS) statistics 24 software. The values are presented as minimum, maximum and standard deviation, that is represented in Table 2.

Table 1. The location and habitats of studied specimens in Salvia.

\begin{tabular}{|c|c|c|c|c|}
\hline Species & Local name & Section & $\begin{array}{l}\text { Collection areas and } \\
\text { coordinates }\end{array}$ & $\begin{array}{c}\text { Voucher } \\
\text { specimen no }\end{array}$ \\
\hline S. bracteata & Çobanşalbası & Salvia & $\begin{array}{l}\text { C8 Mardin; Artuklu, } \\
37^{\circ} 24^{\prime} 41^{\prime \prime} \mathrm{N}-40^{\circ} 41^{\prime} 13^{\prime \prime} \mathrm{E}\end{array}$ & $\begin{array}{l}\text { F Mungan Kılıç. } \\
222\end{array}$ \\
\hline S. macrochlamys & Çölşalbası & Salvia & $\begin{array}{l}\text { C8 Mardin: Artuklu, } \\
37^{\circ} 19^{\prime} 22^{\prime}{ }^{\prime} \mathrm{N}-40^{\circ} 46^{\prime} 04^{\prime \prime} \mathrm{E}\end{array}$ & $\begin{array}{l}\text { F Mungan Kılıç } \\
204\end{array}$ \\
\hline S. suffruticosa & Kalınşalba & Salvia & $\begin{array}{l}\text { C8 Mardin: Artuklu, } \\
37^{0} 23^{\prime} 37^{\prime \prime} \mathrm{N}-40^{0} 40^{\prime} 42^{\prime \prime} \mathrm{E}\end{array}$ & $\begin{array}{l}\text { F Mungan Kılıç } \\
226\end{array}$ \\
\hline S. trichoclada & Meşeşalbası & Salvia & $\begin{array}{l}\text { C8 Mardin; Artuklu, } \\
37^{\circ} 24^{\prime} 41^{\prime \prime} \mathrm{N}-40^{\circ} 41^{\prime} 13^{\prime \prime} \mathrm{E}\end{array}$ & $\begin{array}{l}\text { F Mungan Kılıç } \\
225\end{array}$ \\
\hline S. multicaulis & Kürtreyhanı & Hymenosphace & $\begin{array}{l}\text { C8 Mardin: Mazıdağ } \\
37^{\circ} 27^{\prime} 41^{\prime \prime} \mathrm{N}-40^{0} 26^{\prime} 55^{\prime \prime} \mathrm{E}\end{array}$ & $\begin{array}{l}\text { F Mungan Kılıç } \\
212\end{array}$ \\
\hline S. montbretii & Kabaşalba & Aethiopis & $\begin{array}{l}\text { C8 Mardin: Midyat, } \\
37^{0} 26^{\prime} 13^{\prime \prime} \mathrm{N}-41^{0} 21^{\prime} 06^{\prime} \mathrm{E}\end{array}$ & $\begin{array}{l}\text { F Mungan Kılıç } \\
209\end{array}$ \\
\hline S. palaestina & Sürmelişalba & Aethiopis & $\begin{array}{l}\text { C8 Mardin: K1ziltepe } \\
37^{0} 18^{\prime} 09^{\prime}{ }^{\prime} \mathrm{N}-40^{0} 37^{\prime} 23^{\prime}{ }^{\prime} \mathrm{E}\end{array}$ & $\begin{array}{l}\text { F Mungan Kilıç } \\
201\end{array}$ \\
\hline S. syriaca & Çevlikotu & Aethiopis & $\begin{array}{l}\text { C8 Mardin: Mazıdağ } \\
37^{\circ} 28^{\prime} 00^{\prime \prime} \mathrm{N}-40^{0} 26^{\prime} 42^{\prime \prime} \mathrm{E}\end{array}$ & $\begin{array}{l}\text { F Mungan Kılıç } \\
211\end{array}$ \\
\hline S. russellii & Kurdeşk & Hemisphace & $\begin{array}{l}\text { C8 Mardin: Midyat, } \\
37^{0} 25^{\prime} 45^{\prime}, \mathrm{N}-41^{0} 21^{\prime} 30^{\prime}{ }^{\prime} \mathrm{E}\end{array}$ & $\begin{array}{l}\text { F Mungan Kılıç } \\
210\end{array}$ \\
\hline
\end{tabular}




\section{Results and Discussion}

\section{Pollen morphological analysis}

The pollen properties of nine species were studied by using LM and SEM (Fig. 1). The pollen grain characters of the taxa studied are presented in Table 2. Pollen grains are characterized by radiosymmetric monads and isopolar.
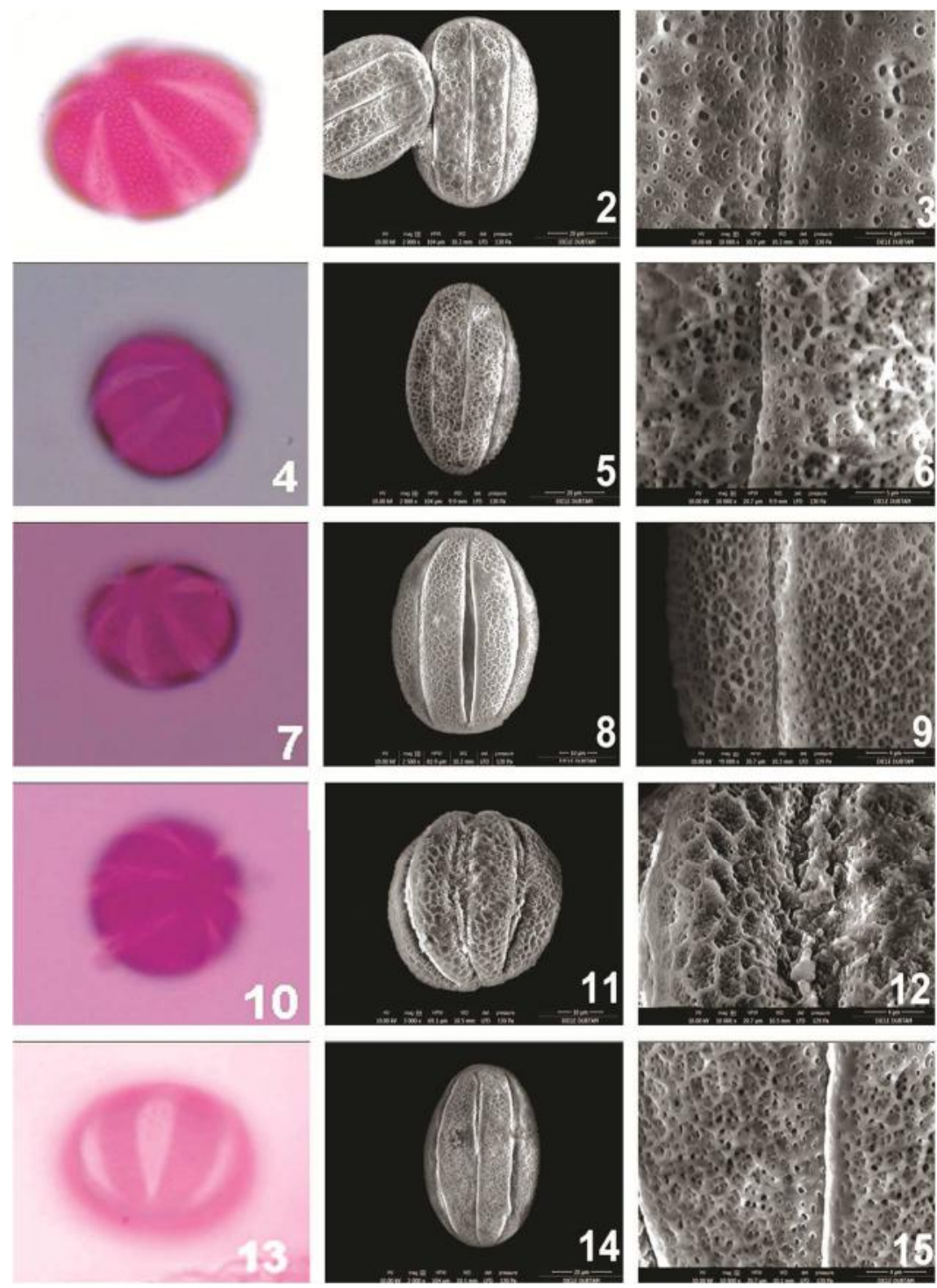

Fig. 1. Pollen grains of Salvia using light microscope (LM) and a scanning electron microscope (SEM); 1-3) Salvia bracteata; 4-6) S. macrochlamys 7-9); S. suffruticosa; 10-12) S. trichoclada; 13-15) S. multicaulis; $1,4,7,10,13$ ) LM overview; $2,5,8,11,14$ ) SEM overview; 3, 6, 9, 12, 15) details of the exine and colpi using an SEM. 


\section{Pollen size}

The average size of pollen grains was from 24.8 to $46.2 \mu \mathrm{m}$ polar length and 30.5 to $56.5 \mu \mathrm{m}$ in equatorial width (Table 2). $S$. palaestina pollen grains with polar length $46,2 \mu \mathrm{m}$ and $56,5 \mu \mathrm{m}$ equatorial width is biggest pollen. $S$. russellii pollen grains with polar length $24,8 \mu \mathrm{m}$ and equatorial width $30,5 \mu \mathrm{m}$ is smallest pollen (Table 2, Fig. 2).
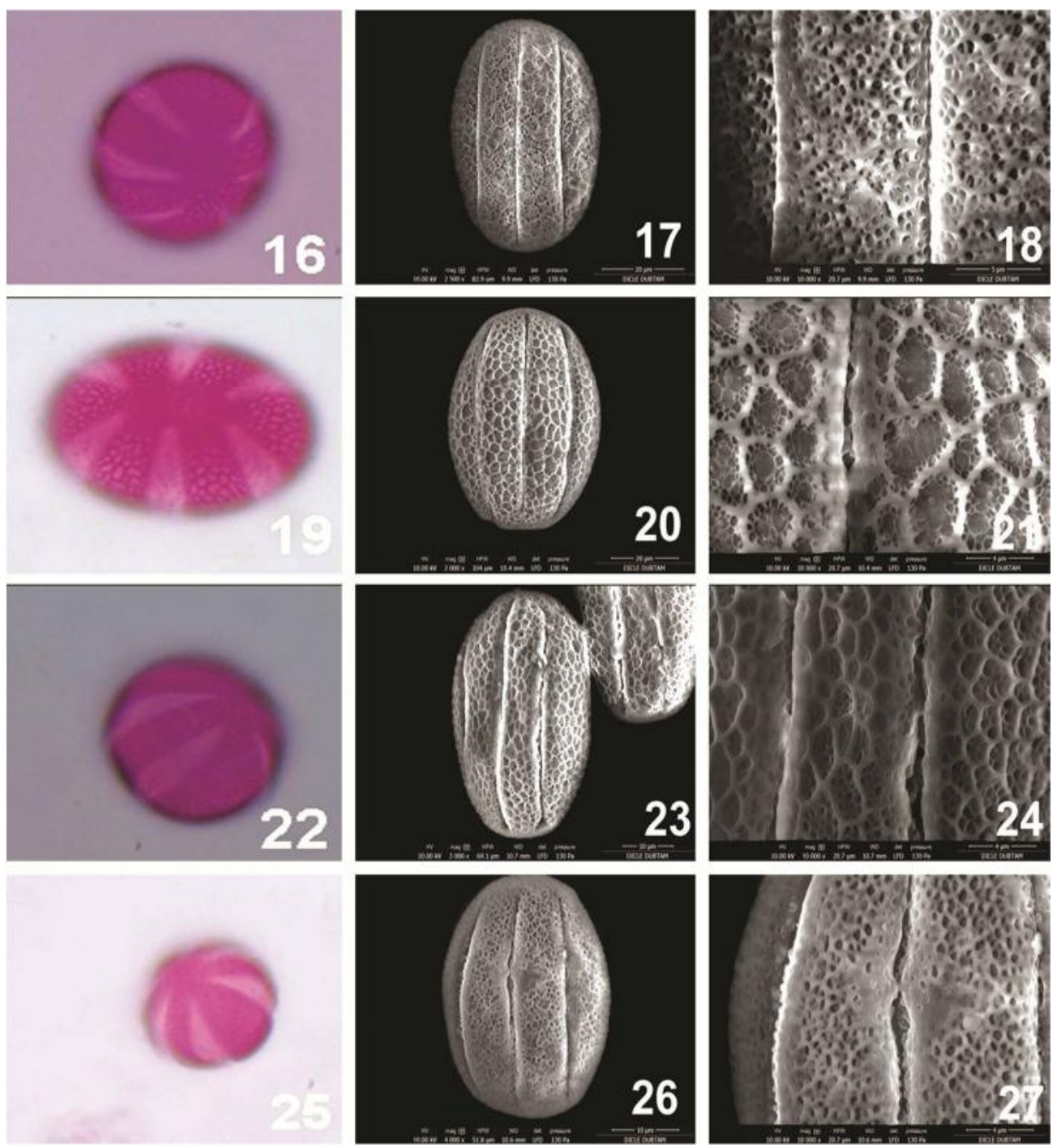

Fig. 1 (Contd.). Pollen grains of Salvia using light microscope (LM) and a scanning electron microscope (SEM); 16-18) Salvia montbretti; 19-21) S. palaestina; 22-24) S. syriaca; 25-27) S. russelli; 16, 19, 22, 25) LM overview; 17, 20, 23, 26) SEM overview; 18, 21, 24, 27) details of the exine and colpi using an SEM.

Pollen shape

Three types of pollen shapes were determined according to $\mathrm{P} / \mathrm{E}$ ratio result.

Type 1: Oblate (P/E ratio $0,50-0.75 \mu \mathrm{m})$; This type is represented by $S$. suffruticosa with $\mathrm{P} / \mathrm{E}$ ratio $0,71 \mu \mathrm{m}$ (Figs 1,3$)$. 


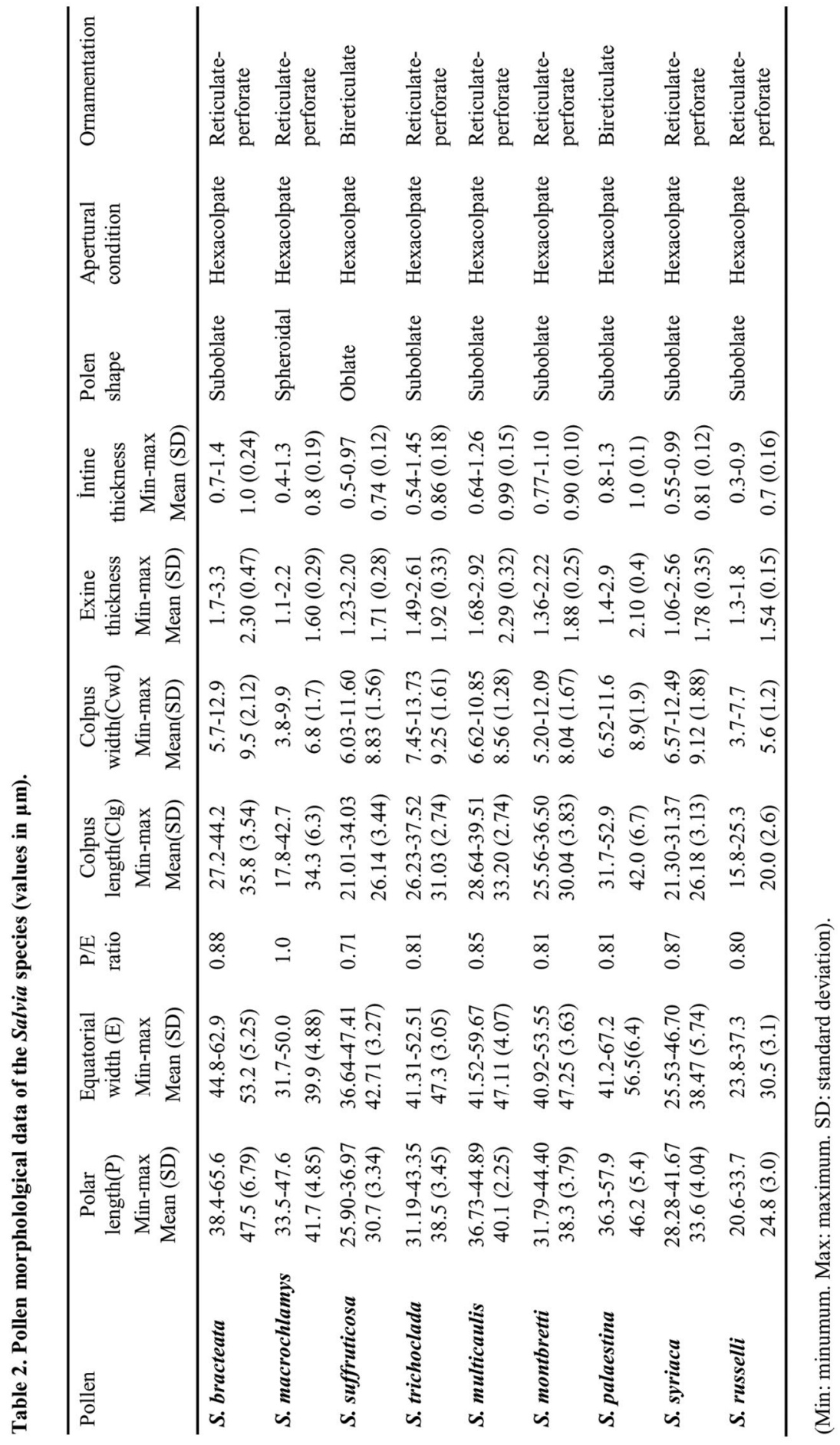


Type 2: Suboblate (P/E ratio $0,76-0.88 \mu \mathrm{m})$; This type is represented by seven species $S$. bracteata, S. trichoclada, S.multicaulis, S. montbretti, S. palaestina, S. syriaca, S. russelli with a range of $\mathrm{P} / \mathrm{E}$ ratio from $0,81 \mu \mathrm{m}$ to $0,88 \mu \mathrm{m}$ (Figs 1,3 ).

Type 1: Spheroidal (P/E ratio $1 \mu \mathrm{m})$; This type is represented by $S$. macrochlamys with $\mathrm{P} / \mathrm{E}$ ratio $1 \mu \mathrm{m}$ (Figs 1,3 ).

Aperture type: All the species of aperture condition is hexacolpate. Colpus length and colpus width mean values were measured 20.0 to $42.0 \mu \mathrm{m}$ and 5.6 to $9.5 \mu \mathrm{m}$, respectively (Table 2 , Fig. 4).

Ornamentation: The exine sculpturing studied taxa were reticulate-perforate and bireticulate. The bireticulate tectum type was found S. palaestina and S. suffruticosa. The other species were reticulate-perforate. The exine thickness is between 1,54-2,30 $\mu \mathrm{m}$ and intine thickness is $0,7-1$ $\mu \mathrm{m}$.(Table 2, Fig. 5).

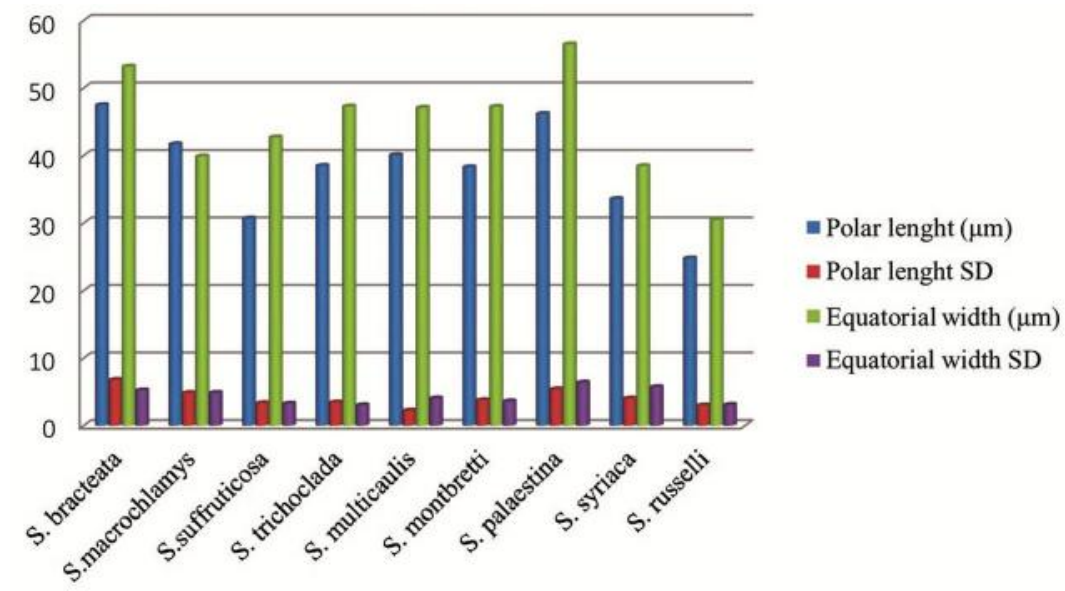

Fig. 2. Polar and Equatorial diameter variations of Salvia species.

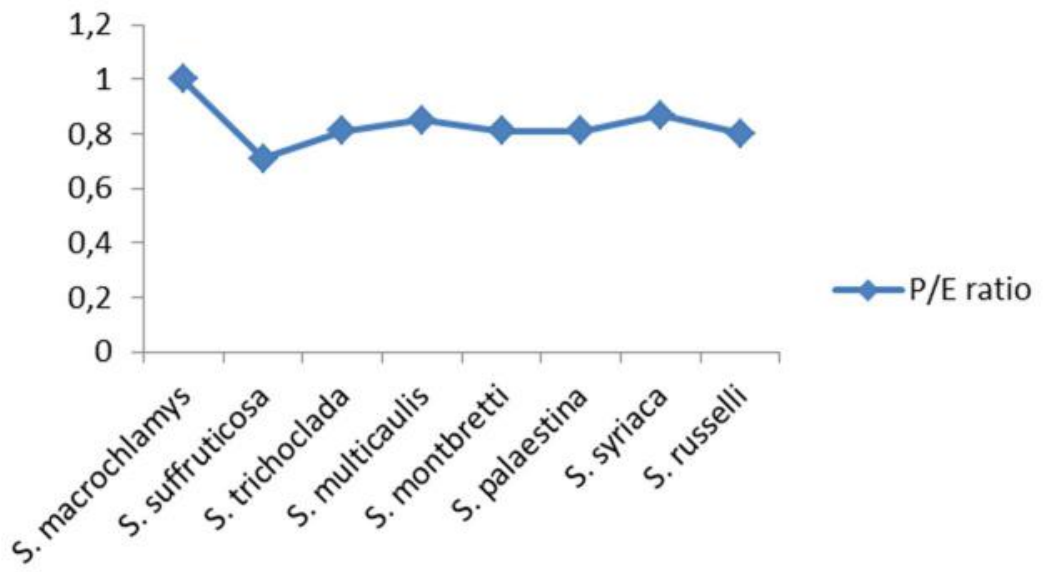

Fig. 3. P/E index of Salvia species 


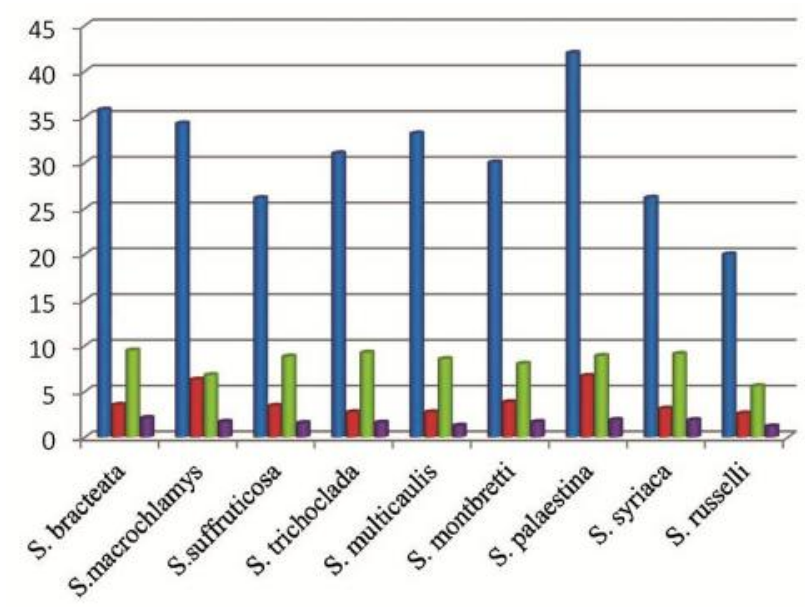

= Colpus lenght $(\mu \mathrm{m})$

$\approx$ Colpus lenght $\mathrm{SD}$

$=$ Colpus width $(\mu \mathrm{m})$

m Colpus width SD

Fig. 4. Colpi length and width variation of Salvia species.

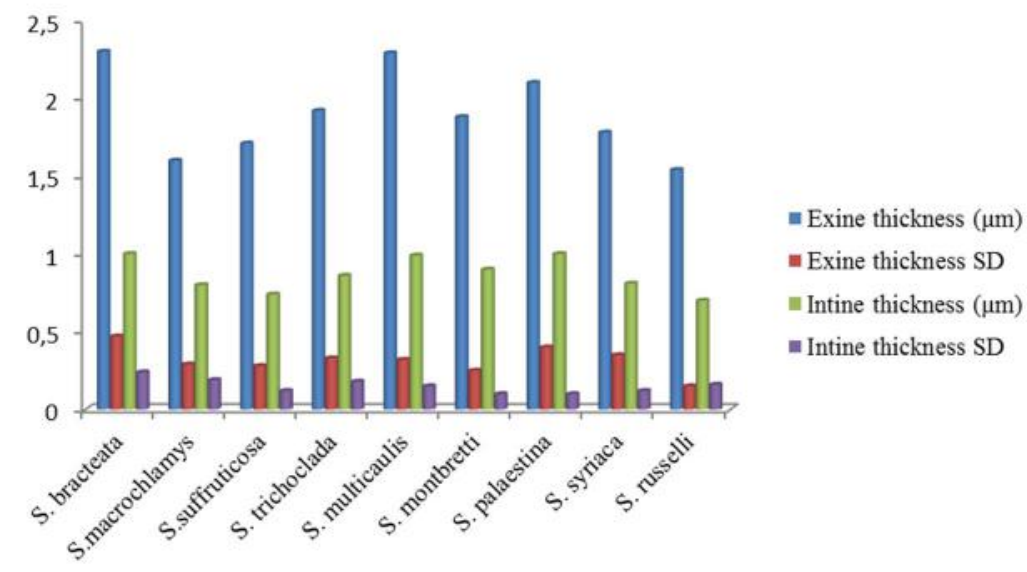

Fig. 5. Variation in exine and intine thickness of Salvia species.

In this study the Salvia species which distributed in Mardin were investigated for morphological pollen qualitative and quantitative characteristics. The specimens were collected from various localities of Mardin.

In our present study of Salvia section: Pollen grains are suboblate, spheroidal and oblate, aperture condition is hexacolpate. Polar length $30,7 \mu \mathrm{m}$ and $47,5 \mu \mathrm{m}$, equatorial width 39,4 to 53,2 $\mu \mathrm{m}$, and reticulate-perforate and bireticulate ornamentation are reported. Özler et al. (2011) reported that Salvia section's pollen suboblate to subprolate and aperture condition is hexacolpate and octacolpate, exine structure are reticulate-perforate, reticulate-granulate and bireticulate. $S$. suffruticosa (sect. Salvia) pollen is subprolate and pollen surface bireticulate observed by Aktaş et al. (2020).

In this study of Hymenosphace section: $S$. multicaulis pollen grain is suboblate, and reticulateperforate sculpture, Özler et al. (2013) and Özler et al. 2020 reported that $S$. multicaulis pollen grain is prolate-spheroidal aperture condition is reticulate-perforate. 
In our study, Aethiopis section's species S. monbretii, S. syriaca, S. palaestina pollen are suboblate, and aperture condition $S$. monbretii, $S$. syriaca are reticulate-perforate, S. palaestina is bireticulate. Hassan et al. (2009) investigated seven Salvia species in Egypt and bireticulate sculpture in S. palaestina, pollen grain is suboblate to spheroidal. Moon et al. (2008) reported that bireticulate ornamentation in pollen of Aethiopis section. Özler et al. (2013) and Özler et al. 2020 observed that $S$. syriaca characterized by reticulate-perforate, $S$. palaestina is bireticulate exine sculpturing pattern.

In this study of Hemisphace section: S. russellii pollen grain is suboblate, and reticulateperforate sculpture. Ranjbar et al. (2015) indicated that pollen grains of Hemisphace were hekzacolpate and reticulate ormanentation. Özler et al. (2020) in their study noticed Hemisphace species are smaller than the other sections, S. russellii pollen grain is oblate-spheroidal, and bireticulate exine ornamentation.

Differences were observed between the results obtained in our study, together with the other related studies about Salvia. Özler et al. (2013) and Özler et al. 2020) reported that, different results are obtained when Salvia species are examined in terms of shape and size, and they claimed that this differences were due to the tecniques used.

In addition, pollen characteristics of the taxa were determined mostly similar each other in our study. There were no significant differences among the palynological properties of the studied taxa. The pollen morphology does not appear to be useful as a taxonomic technique in the identification of Salvia species. We believe that the results of the present study are important for taxonomically and evolution in/inter the group concerned. Such results will be the base for future biosystematic studies in Salvia.

\section{References}

Ahmad, M., Zafar, M., Sultana, S., Ahmad, M., Abbas, Q., Ayoub, M. and Ullah, F. 2018. Identification of green energy ranunculaceous flora of district Chitral, Northern Pakistan using pollen features through scanning electron microscopy. Microscopy Research and Technique 81(9): 1004-1016.

Aktaş, K., Özdemir, C., Özkan, M. and Baran, P. 2020. Pollen Morphology of Some Turkish Salvia L. (Lamiaceae: Mentheae) Species. Planta daninha. 38

Castro, S., Silveira, P., Navarro, L., Paiva, J. and Coutinho, A.P. 2009. Pollen morphology of Chamaebuxus (DC.) Schb., Chodatia Paiva and Rhinotropis (Blake) Paiva (Polygala L., Polygalaceae). Grana 48(3): 179-192.

Celep, F., Dogan, M. and Duran, A. 2009. A new record for the Flora of Turkey Salvia viscosa Jacq. (Labiatae). Turk. J. Bot. 33: 57-60.

Celep, F., Dogan, M. and Bagherpour, S. 2009. A New Variety of Salvia sericeotomentosa (Lamiaceae) from South Anatolia, Turkey. Novon 19: 432-435.

Celep, F. and Dogan, M. 2010. Salvia ekimiana (Lamiaceae), a new species from Turkey. Ann. Bot. Fennici 47: 63-66.

Celep, F., Doğan, M. and Kahraman, A. 2010. Re-evaluated conservation status of Salvia (sage) in Turkey I: Th e Mediterranean and the Aegean geographic regions. Turk J Bot 34: 201-214.

Erdtman, G. 1945. Pollen morphology and plant taxonomy. IV. Labiatae, Verbanaceae and Avicenniaceae. Svensk Bot. Tidskr. 39: 279-285.

Guimaraes, J.T.F., Carreira, L.M.M,, Alves. R., Martins, e Souza, Filho, P.W., Giannini, T.C. and Macambira, H.J. 2018. Pollen morphology of the Poaceae: Implications of the palynological and paleoecological records of the southeastern Amazon in Brazil. Palynology 42(3): 311-323.

Hassan, N., Osman, A.K., El. and Garf, I.A. 2009. Pollen types of the Egyptian species of the genus Salvia (Lamiae). Feddes Repert 120: 394-404. 
Hedge, I.C. 1982. Salvia L. In: Davis PH (ed.) Flora of Turkey and the East Aegean Islands. 7. Edinburgh: Edinburgh Univ Press, pp. 400-461.

İlçim, A., Celep, F. and Doğan, M. 2009. Salvia marashica (Lamiaceae), a new species from Turkey. Ann. Bot. Fenn. 46: 75-79.

Kahraman, A., Celep, F. and Dogan, M. 2009. Comparative morphology, anatomy and palynology of two Salvia L. species (Labiatae) and their taxonomic implications. Bangl. J. Plant Taxon. 16: 73-82.

Kahraman, A., Celep, F. and Doğan, M. 2010. Morphology, anatomy, palynology and nutlet micromorphology of Salvia macrochlamys (Labiatae) in Turkey. Biologia 6: 219-227.

Moon, H.K., Vinckier, S., Walker, J.B., Smets, E. and Huysmans, S. 2008. A search for phylogenetically informative pollen characters in the subtribe Salviinae (Mentheae: Lamiaceae). Int. J. Plant Sci. 169: 455-471.

Özler, H., Pehlivan, S., Kahraman, A., Doğan, M., Celep, F., Başer, B., Yavru, A. and Bagherpour, S. 2011. Pollen morphology of the genus Salvia L. (Lamiaceae) in Turkey. Flora 206: 316-327.

Özler, H., Pehlivan, S., Celep, F., Doğan, M., Kahraman, A., Yavru, Fişne. A., Başer, B. and Bagherpour, S. 2013. Pollen morphology of Hymenosphace and Aethiopis sections of the genus Salvia (Lamiaceae) in Turkey. Turkish J. Bot. 37: 1070-1084.

Özler, H., Kahraman, A., Pehlivan, S., Doğan, M., Başer, B., Yavru, Fişne, A. and Bagherpour, S. 2020. Contribution to the knowledge of the pollen morphology of the genus Salvia (Lamiaceae), Phytotaxa, 428(3): 228-240.

Punt, W., Hoen, P.P., Blackmore, S., Nilsson, S. and Le Thomas, A. 2007. Glossary of pollen and spore terminology. Rev. Palaeobot. Palynol. 143: 1-81.

Ranjbar, M., Pakatchi, A. and Radjabian, T. 2015. Pollen morphology study of Salvia sect. Plethiosphace and sect. Hemisphace (Lamiaceae) in Iran. Nova Biologica Reperta. 1(2): 16-28.

Walker, J.B. and Sytsma, K.J. 2007. Staminal evolution in the genus Salvia (Lamiaceae): molecular phylogenetic evidence for multiple origins of the staminal lever. Ann. Bot. 100: 375-391.

Wodehouse, R.P. 1935. Pollen Grains. McGraw Hill, New York. 